Provided for non-commercial research and education use. Not for reproduction, distribution or commercial use.

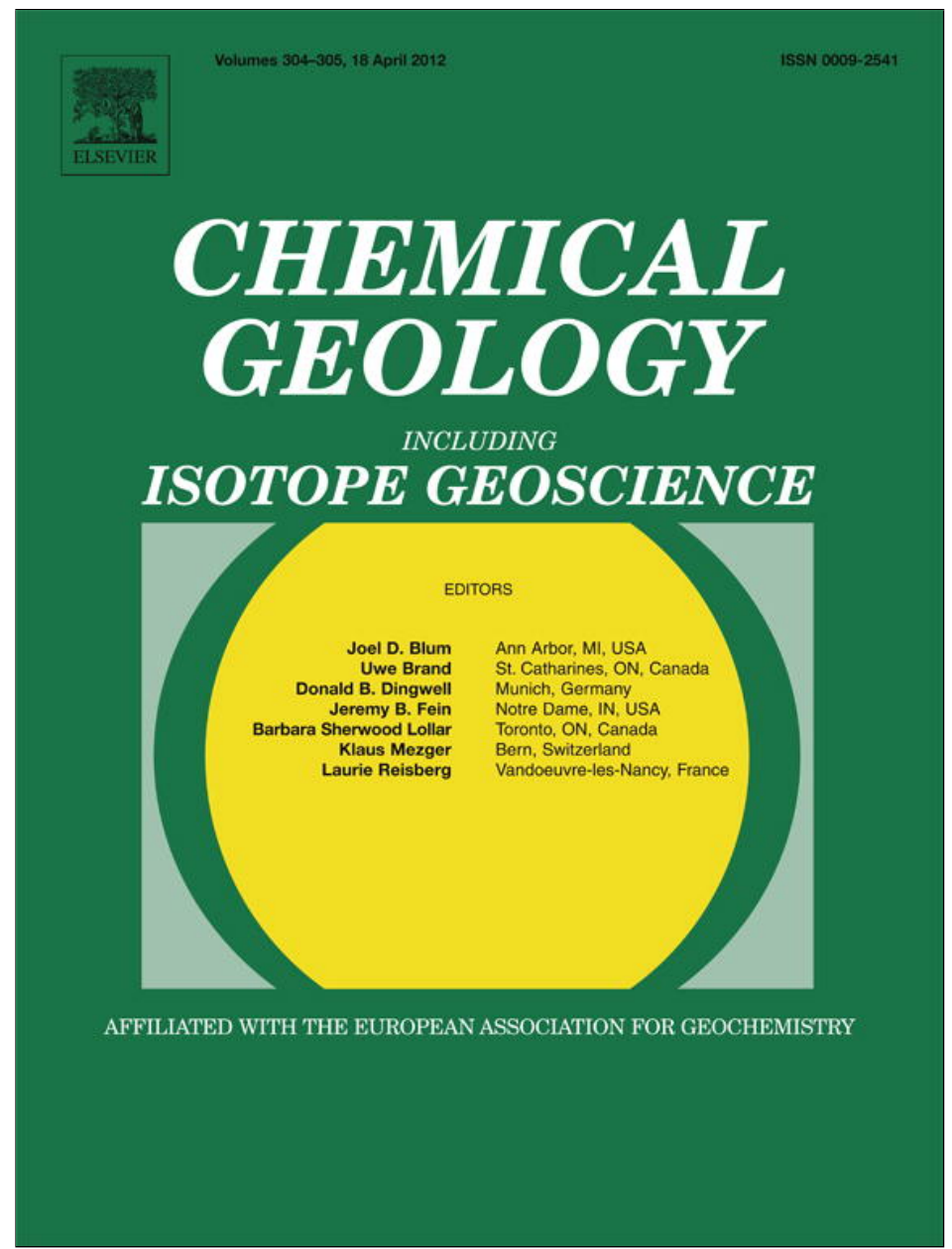

This article appeared in a journal published by Elsevier. The attached copy is furnished to the author for internal non-commercial research and education use, including for instruction at the authors institution and sharing with colleagues.

Other uses, including reproduction and distribution, or selling or licensing copies, or posting to personal, institutional or third party websites are prohibited.

In most cases authors are permitted to post their version of the article (e.g. in Word or Tex form) to their personal website or institutional repository. Authors requiring further information regarding Elsevier's archiving and manuscript policies are encouraged to visit:

http://www.elsevier.com/copyright 


\title{
Noble gas isotopes in hydrothermal volcanic fluids of La Soufrière volcano, Guadeloupe, Lesser Antilles arc
}

\author{
L. Ruzié ${ }^{\mathrm{a}, *}$, M. Moreira ${ }^{\mathrm{a}}$, O. Crispi ${ }^{\mathrm{b}}$ \\ a Équipe de Géochimie et Cosmochimie, Institut de Physique du Globe de Paris, Sorbonne Paris Cité, Univ Paris Diderot, UMR 7154 CNRS, F-75005 Paris, France \\ b Observatoire Volcanologique et Sismologique de Guadeloupe (OVSG) IPGP, UMR CNRS 7154, Le Houëlmont, 97113 Gourbeyre, Guadeloupe (FWI), France
}

\section{A R T I C L E I N F O}

\section{Article history:}

Received 8 July 2011

Received in revised form 15 February 2012

Accepted 16 February 2012

Available online 24 February 2012

Edited by L. Reisberg

\section{Keywords:}

Noble gas isotopes

Soufrière of Guadeloupe

Hydrothermal fluids

Magma degassing

\begin{abstract}
A B S T R A C T
The ascending magmatic component in La Soufrière volcano (Guadeloupe, Lesser Antilles) was investigated by measuring noble gas concentrations and isotopic ratios in thermal springs and fumaroles. A clear magmatic helium signal $\left({ }^{4} \mathrm{He} /{ }^{3} \mathrm{He} \sim 89,000\right.$; R/Ra $\left.~ 8\right)$, equivalent to the MORB value, is recorded in most fluids. ${ }^{3} \mathrm{He}$ fluxes in both fumarole and springs have been estimated and related to ${ }^{3} \mathrm{He}$ content in the magma chamber. In order to explain the ${ }^{3} \mathrm{He}$ flux measured at the surface, we conclude that the magma chamber must be regularly fed by fresh magma batches. Using our new results and data from literature, we propose that the historical activity of La Soufrière volcano can be explained by both abnormal energy inputs from new batches of magma in the chamber and cycles of clogging/opening of the hydrothermal system. We propose a new scenario for the origin of the 1976-1977 crisis whereby a fresh batch of magma could have been emplaced prior to 1968 (possibly between 1959 and 1962) in the magma chamber. The resulting heat flux is not stored in the different aquifers but preferentially evacuated through fractures reactivated or created during the 1956 phreatic eruption. Only when the self-sealing of the hydrothermal system is sufficiently developed, can pressure and temperature within the aquifers rapidly increase to trigger a crisis.
\end{abstract}

(c) 2012 Elsevier B.V. All rights reserved.

\section{Introduction}

Volcanic emissions of gases to the atmosphere take many different forms - from hydrothermal manifestations to massive syn-eruptive releases. Understanding the relationship between the gases released and magma evolution is central for monitoring and forecasting volcanic eruptions. Analyses of gas and fluid samples collected at the surface can reveal important information on degassing activity inside the magma chamber. However hydrothermal systems on some volcanoes, particularly in tropical areas, can buffer the magmatic signal, thereby complicating its interpretation. Therefore, we need to use conservative tracers to avoid any external perturbations. Noble gases are of particular interest because they are chemically inert and they behave as incompatible elements during melting and crystallization. Specifically, helium systematics are very useful for distinguishing magmatic signals (high ${ }^{3} \mathrm{He}$ isotope content) from crustal contamination $\left({ }^{4} \mathrm{He}\right.$ production by $\mathrm{U}$ and $\mathrm{Th}$ ) and air/water contamination.

Indeed, glassy margins from Mid-Oceanic Ridge Basalts (MORB) show a relatively homogeneous ${ }^{4} \mathrm{He} /{ }^{3} \mathrm{He}$ ratio of $89,000 \pm 10,000$ (or $\mathrm{R} / \mathrm{R}_{\mathrm{a}}=8 \pm 1$ with $\mathrm{R}={ }^{3} \mathrm{He} /{ }^{4} \mathrm{He}$ and $\mathrm{R}_{\mathrm{a}}$, the atmospheric ratio $=$ $1.4 \times 10^{-6}$ ) (Allègre et al., 1995) whereas oceanic and continental

* Corresponding author at: School of Earth, Atmospheric and Environmental Sciences, The University of Manchester, Oxford Road, Manchester M13 9PL, UK.

E-mail address: lorraine.ruzie@manchester.ac.uk (L. Ruzié). crusts, which are degassed, have more radiogenic isotopic ratios $\left({ }^{4} \mathrm{He} /{ }^{3} \mathrm{He}\right.$ up to $10^{7}$ or $\left.\mathrm{R} / \mathrm{R}_{\mathrm{a}}<0.1\right)$ depending on their age (Staudacher and Allègre, 1988; Drescher et al., 1998; Moreira et al., 2003). Atmospheric helium is the result of mantle and crust degassing and helium loss to space, leading to a ratio of $\sim 720,000$ $\left(\mathrm{R} / \mathrm{R}_{\mathrm{a}}=1\right)$. Most subduction-related volcanoes have helium isotopic ratios between the MORB value and the crustal value, reflecting crustal contamination, magma chamber degassing and radiogenic ingrowth (Hilton et al., 2002).

La Soufrière volcano in Guadeloupe Island (Lesser Antilles) is active and has been the site of several phreatic eruptions since at least the 17 th century. It has a large hydrothermal system, which has been well studied through monthly sampling carried out by the Volcanological Observatory since 1979. Previous studies on the Lesser Antilles arc have shown that La Soufrière volcano is sampling a MORB-like source for helium (van Soest et al., 1998; Pedroni et al., 1999), suggesting a negligible sedimentary contribution, as well as insignificant crustal contamination in the magmatic source of this volcano. Therefore, for all these reasons, La Soufrière volcano is an ideal target for constraining magma degassing behaviour through hydrothermal manifestations. In this study, detailed magmatic volatile fluxes were estimated using helium isotopes in fumaroles and thermal springs. Surveys were conducted between 2007 and 2010. In addition, we give an overview of the activity of La Soufrière volcano over the past-500 years. Using the new dataset and previous studies, we propose that the historical behaviour of the volcano can be explained 
through a balance between arrivals of fresh batches of magma in the reservoir and clogging/opening cycles of the hydrothermal system.

\section{Geological setting}

Westward subduction of the Atlantic plate at $2.2 \mathrm{~cm} / \mathrm{year}$ has given rise to the Lesser Antilles, a 750-km-long-intra-oceanic-north-south trending volcanic arc, located on the eastern margin of the Caribbean plate (Fig. 1A). In Guadeloupe, activity of the Grande-Découverte/La Soufrière composite volcano began about 200,000 years ago. The building phase of the primitive complex terminated with a Plinian eruption, which was the largest in the entire history of the volcano. This event, called "Pintade", formed a caldera of which only the northern rim remains. This first stage, named "Grande Découverte" ended 42,000 years ago. The volcanic activity continued within each newly formed caldera until 11,500 years ago. This second stage terminated with two flank collapses (Boudon et al., 1987; Komorowski et al., 2005). The last stage, called "Soufrière," is characterised by several southward flank destabilisations. One of the most important took place 3100 years ago. This StHelens-type eruption formed the Amic crater $(1.7 \times 1.3 \mathrm{~km})$ where the present activity is located (Boudon et al., 1987) (Fig. 1B).

The last magmatic eruption (1530 AD) started with a small flank destabilisation followed by a subplinian eruption (Boudon et al., 2008). The eruption ended with growth of the present lava dome. Semet et al. (1981) estimated the volume of La Soufrière magma chamber to be $0.08-0.1 \mathrm{~km}^{3}$ based on volumes of eruptive products of that last magmatic eruption. The magma chamber depth was estimated at $6.2 \pm$ $0.6 \mathrm{~km}$ using water content of glass inclusions in plagioclase crystals (Semet et al., 1981). This is strongly supported by seismic data (6.4 km) (Hirn and Michel, 1979) and magnetic observations (5-8 km) (Pozzi et al., 1979). Furthermore, that eruption produced a large compositional range of volcanic products, from andesite to basaltic andesite. Magma compositions are derived from a homogenous source but it seems they have evolved separately. Therefore, mixing of melts with variable degrees of differentiation influences erupted magma (Semet et al., 1981; Poussineau, 2005; Touboul et al., 2007).

The main magma chamber seems to be chemically and thermally zoned. Hot percolating magma and/or new batches of fresh magma probably carry heat from a deeper source of basaltic magma. Each new injection remains partially isolated from resident melts. When a significant fresh injection of basaltic magma rises into the andesitic chamber, mechanical mixing should occur, generating fluid overpressure and/or rock fracturation, triggering eruption (Poussineau, 2005). In addition, $\mathrm{U}$-series disequilibria require the existence of a long-lived zoned magma chamber ( $65 \mathrm{kyr}$ ) that behaved as an open system (Touboul et al., 2007). Touboul et al. (2007) assume the existence of a shallow intrusion in order to explain age dichotomies between old crystals (>35 kyr) and young liquid. This shallow intrusion above the main magma chamber could evolve as a closed system. Villemant et al. (2005) use also the shallow intrusion hypothesis to explain chlorine contents of thermal springs. This shallow intrusion could have degassed in pulses since its emplacement in 1973 and could be the trigger of the last phreatic crisis in 1976-77. This potential $25-\mathrm{m}$ radius intrusion (around $10^{-4} \mathrm{~km}^{3}$ ) is located at $3 \mathrm{~km}$ depth in the $2-5 \mathrm{~km}$ range corresponding to earthquake migration during the 1976-77 period (Feuillard et al., 1983). Another physical model suggests a bigger intrusion with a radius between 150 and $500 \mathrm{~m}\left(0.01\right.$ and $\left.0.52 \mathrm{~km}^{3}\right)$ emplaced at $2-5 \mathrm{~km}$ depth to explain the evolution of chlorine content in thermal springs (Boichu et al., 2008).

We observe that the origin of the last phreatic crisis is still debated in the literature. The first scenario - a still-born magmatic eruption involves a change in the magma chamber caused by the arrival of a new batch of magma, or by the emplacement of an intrusion (Feuillard et al., 1983; Villemant et al., 2005; Boichu et al., 2008). The second scenario (Zlotnicki et al., 1992) calls for no change in the magmatic

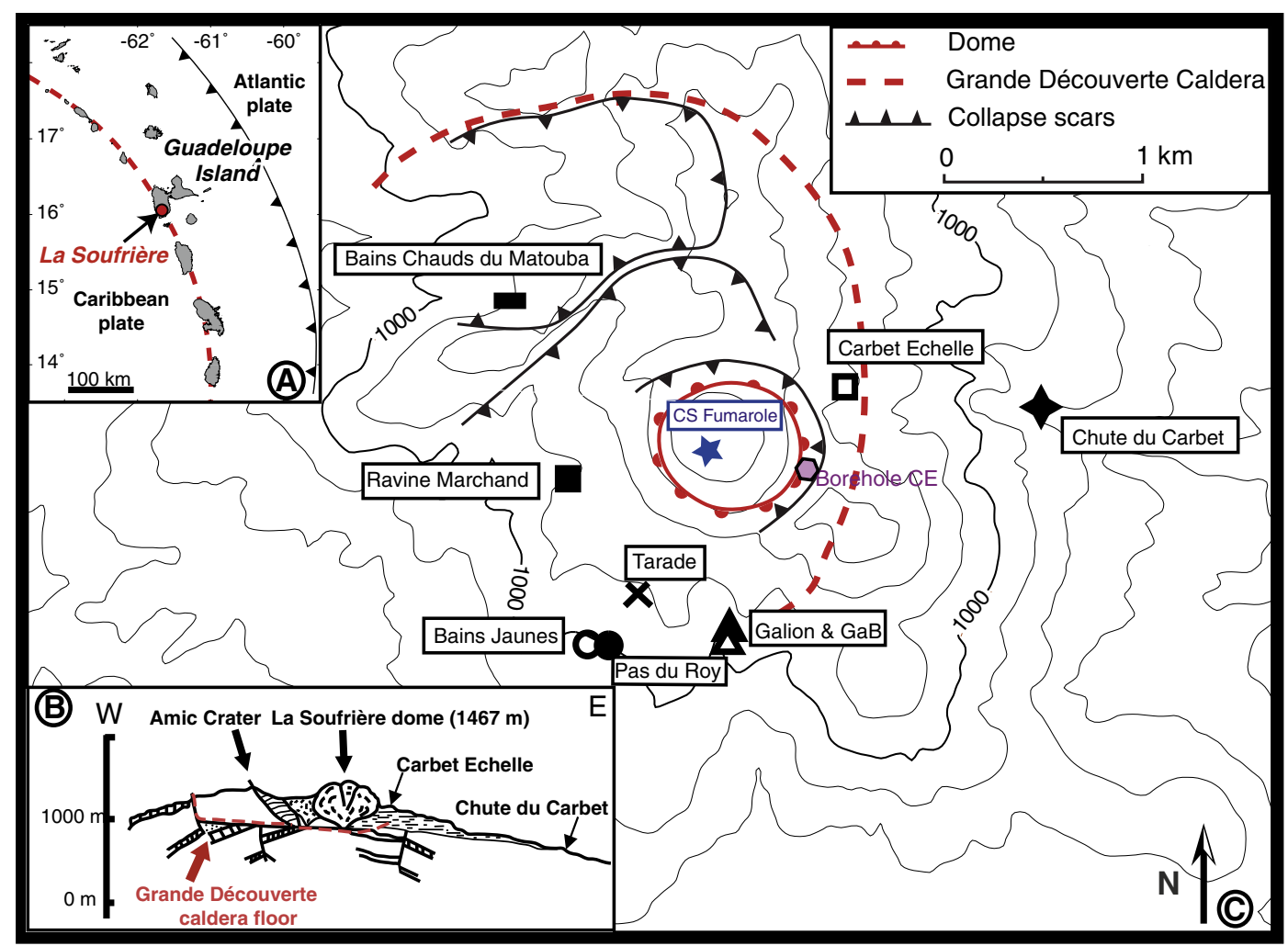

Fig. 1. A) Map of the Lesser Antilles Volcanic Arc. B) Schematic E-W cross-section showing the main geological structures of the volcanic growth (modified from Villemant et al., 2005). C) Structural map of La Grande Découverte/Soufrière volcanic complex showing the locations of the surveyed thermal springs (except Habitation Revel, which lies 5 km from the dome towards the west), Crater South fumarole and Col de l'Echelle borehole (modified from Boichu et al., 2008). 
reservoir and is based only on hydrothermal activity. The origin of eruption could be a self-sealing phenomenon associated with dome fissure compaction and argillization, which significantly reduces heat transfer towards the volcano summit. The pressure increases in the deep aquifer generating new cracks and/or reopening old ones. When the last watertight layer above the phreatic reservoir is fractured, explosion occurs.

As the hydrothermal system plays a key role in the activity evolution at La Soufrière, it has been the subject of numerous studies since 1976. The hydrothermal activity manifests itself as fumaroles, thermal springs and diffuse soil degassing in the vicinity of faults (Allard et al., 1998). Fumaroles are limited to the dome area, while springs are located in a $5-\mathrm{km}$ diameter area around the dome (Fig. 1C).

The spatial distribution of thermal springs and fumaroles is controlled by geological structures inherited during growth of the volcano (Zlotnicki et al., 2006). All thermal springs are supplied by meteoric water as shown by $\delta^{18} \mathrm{O}$ and $\delta \mathrm{D}$ data (Benauges, 1981; Brombach et al., 2000). Dome structure and meteoric water percolation in the edifice have previously been determined experimentally through field studies using chemical tracers (Bigot et al., 1994), Very Low Frequency (VLF) survey (Zlotnicki et al., 2006) and electrical tomography (Nicollin et al., 2006). Sealed areas in the western part of the dome prevent fumarole formation and thermal spring emergence with the exception of those far from the dome centre and/or in narrow valleys, e.g. Ravine Marchand or above major faults, e.g. Bains Chauds du Matouba. Areas with fresh pyroclastic deposits and/or opened fractures show a strong fumarolic activity and a lot of water emergence. Hot mineralized waters of Galion and Carbet Echelle drain these fields (Pascaline et al., 1982).

\section{Sample collection and analytical methods}

Gas from South Crater fumaroles was collected twice in April 2007 and October 2010 using the routine method of the observatory. A tube was inserted in the fumarole as deep as possible to prevent air contamination. A condenser was connected to the tube to remove water. Before introducing the gas we flushed the system several times (LeGuern et al., 1993). In April 2007 gas was collected using a glass-bottle; analyses were conducted two weeks after the sampling to avoid helium diffusion. In 2010 gas was sampled in preevacuated stainless-steel bulbs with stopcocks. Rare gases from both samples were measured on the ARESIBO II glass-mass-spectrometer using the same procedure described in Moreira and Allègre (2002). Concentrations were determined by signal comparison with air standards, which were processed in the same way as our samples and corrected for pressure. A Reunion standard $\left({ }^{4} \mathrm{He} /{ }^{3} \mathrm{He}=56,450\right.$ or $\mathrm{R} / \mathrm{R}_{\mathrm{a}}=12.68$ ) was used for isotope ratio calibration.

Nine thermal springs were sampled in July 2007, May 2009 and October 2010. The springs are: Ravine Marchand (RM), Galion (GA), Carbet-Echelle (CE), Chute du Carbet (CC), Bains Jaunes (BJ), Pas du Roy (PR), Bains Chauds du Matouba (BCM), Tarade (TA) and Habitation Revel (HR) (Fig. 1C). To collect water samples, we used copper tubes, tightly closed at both ends by steel clamps, after repeated tube flushing. Helium and neon measurements were conducted on water samples using a Quadrupole Mass-Spectrometer (QMG220, Pfeiffer@) for concentration and a Noblesse (Nu Instruments $\odot$ ) mass-spectrometer for helium and neon isotopic compositions. To extract fluid samples from sealed copper tubes and remove reactive gases, we use the Garodiox line designed by Stéphane Lafortune and modified by Claire Gréau. It is divided into two main sections: a sample release part and a gas preparation section. The first section comprises a sample inlet where the copper tube is fixed, a degassing bulb and a glass $\mathrm{H}_{2} \mathrm{O}$-vapor trap cooled with liquid nitrogen. In the second part, residual gases are purified using two hot Ti-getters. Purified gases are then separated into two volumes. One is dedicated to QMG220 measurements; the other part is driven towards a charcoal trap for helium and neon separation before analysis on the Noblesse mass-spectrometer. Concentrations and isotopic ratios were determined by signal comparison with air-saturated water samples, which were processed using the same method as the samples. Blanks represent between 2 and $9 \%$ of the helium and around $2 \%$ of the neon measured in the water samples.

\section{Results}

\subsection{Thermal springs}

Helium and neon concentrations and isotopic ratios in water samples are listed in Table 1 . Helium concentrations vary between $8.8 \times 10^{-8}$ cCSTP/gH $/ \mathrm{gH}_{2} \mathrm{O}$ in Habitation Revel and $2.2 \times 10^{-7} \mathrm{ccSTP} / \mathrm{gH}_{2} \mathrm{O}$ in Ravine Marchand spring. Fig. 2 is a plot of ${ }^{3} \mathrm{He} /{ }^{4} \mathrm{He}$ normalized by air ratio $\left(\mathrm{R}_{\mathrm{a}}=1.4 \times 10^{-6}\right)$ versus ${ }^{22} \mathrm{Ne} /{ }^{4} \mathrm{He}$ for all water samples investigated. It is well documented that MORB samples have a constant ${ }^{4} \mathrm{He} /{ }^{3} \mathrm{He}$ ratio of around 89,000 (or ${ }^{3} \mathrm{He} /{ }^{4} \mathrm{He}=8 \pm 1 \mathrm{R}_{\mathrm{a}}$ ) (Allègre et al., 1995), which represents a mean upper mantle value. Helium isotopic ratios in water samples were corrected for contamination using the measured ${ }^{4} \mathrm{He} /{ }^{22} \mathrm{Ne}$ ratios and assuming a pure air-saturated water (ASW) origin for neon as indicated by neon isotopic ratio measurements (Table 1). Indeed, neon isotopic ratios are very close to the air value $\left({ }^{20} \mathrm{Ne} /{ }^{22} \mathrm{Ne}=9.8\right.$ and $\left.{ }^{21} \mathrm{Ne} /{ }^{22} \mathrm{Ne}=0.0290\right)$ suggesting that neon is purely of atmospheric origin and that the mantle neon is negligible.

Corrections vary between 7\% for Ravine Marchand and 91\% for Bains Jaunes. For contamination greater than $70 \%$, data were not corrected (Bains Jaunes and Pas du Roy). After correction, six springs display ${ }^{4} \mathrm{He} /{ }^{3} \mathrm{He}$ ratios close to 89,000 . So, La Soufrière thermal springs clearly show lower ${ }^{4} \mathrm{He} /{ }^{3} \mathrm{He}$ values than that of the atmosphere $(720,000)$, with the lowest values similar to those of MORB. It clearly indicates a magmatic origin of these gases as shown by Allard et al. (1983), Pedroni et al. (1999), van Soest et al. (1998). Two thermal springs show higher ${ }^{4} \mathrm{He} /{ }^{3} \mathrm{He}$ : Chute du Carbet $(108,000 \pm 4,000)$ and Habitation Revel $(124,000 \pm 400)$. These are located further away from the volcanic summit ( $2 \mathrm{~km}$ and $5 \mathrm{~km}$ respectively).

No major changes in helium concentration occurred for each spring during 3 years, except for Habitation Revel, where ${ }^{4} \mathrm{He}$ concentration increased from $1.4 \times 10^{-8}$ to $8.8 \times 10^{-8} \mathrm{ccSTP} / \mathrm{g}$, without changing the isotopic ratio. Furthermore, two distinct groups appear independent of spring characteristics: (1) springs with helium concentrations between 4 and $8 \times 10^{-8} \mathrm{ccSTP} / \mathrm{g}(\mathrm{BJ}, \mathrm{GaB}, \mathrm{Ga}, \mathrm{PR}, \mathrm{TA})$ and (2) springs with helium concentrations between 14 and $22 \times 10^{-8} \mathrm{cCSTP} / \mathrm{g}$ (CE, RM, CC, BCM). In Fig. 1C, we see that members of the first group are located in a narrow area (less than $1 \mathrm{~km}^{2}$ ) in the southern part of the dome.

\subsection{Fumarole}

Concentration and isotopic ratios for all noble gas data in South Crater are presented in Table 2, where we compare our data with air and previous measurements made in 1995 by Pedroni et al. (1999).

Noble gas data are shown using the fractionation factor, $F(X)=$ $\left(\mathrm{X} /{ }^{36} \mathrm{Ar}\right)_{\text {sample }} /\left(\mathrm{X} /{ }^{36} \mathrm{Ar}\right)_{\text {air }}$ in order to compare elemental ratios with atmospheric ratios. Results are reported in the Table 2 . Results for 2007 and 2010 are globally similar, though in detail some differences are observed. Variations of $\mathrm{F}\left({ }^{4} \mathrm{He}\right)$ between 2007 and 2010 could be explained by a higher air contamination in 2010 during the sampling phase. This assumption is confirmed by the $\mathrm{F}\left({ }^{20} \mathrm{Ne}\right)$ equivalent to air in the 2010 sample and by the lower ${ }^{4} \mathrm{He} /{ }^{22} \mathrm{Ne}$ ratio in 2010 (56.3) than in 2007 (442), which clearly indicates air addition. Fractionation factors for krypton and xenon are higher than 1 in both samples. If the trends were caused by mass fractionation from the atmospheric value, the fumarole gases would be enriched in the light elements, that is fractionation factor would be less than 1 for xenon and krypton. The fractionation trends for heavy noble gases (krypton and xenon) are therefore produced by mixing between two components (Sumino et al., 2004). One of them could be air-saturated water $\left(\mathrm{F}^{84} \mathrm{Kr}=1.85\right.$ and $\left.\mathrm{F}^{132} \mathrm{Xe}=3.3\right)$. Regarding isotopic ratio results, we 
Table 1

Helium and neon concentrations and isotopic ratios for water samples. Year of sampling is indicated in sample name (e.g. GUA07 for 2007).

\begin{tabular}{|c|c|c|c|c|c|c|c|c|c|c|c|c|c|c|c|c|c|c|}
\hline sample & Location & $\begin{array}{c}\text { Lat. } \\
\text { (WGS84) }\end{array}$ & $\begin{array}{c}\text { Long. } \\
\text { (WGS84) }\end{array}$ & $\begin{array}{l}\text { Alt. } \\
\text { (m) }\end{array}$ & $\begin{array}{l}\text { Temp. } \\
\left({ }^{\circ} \mathrm{C}\right)\end{array}$ & $\mathbf{R} / \mathbf{R a}_{\mathrm{m}}$ & $\mathbf{s}$ & $\begin{array}{c}{ }^{4} \mathrm{He} \\
\left(10^{-8} \mathrm{ccSTP} / \mathrm{g}\right)\end{array}$ & ${ }^{20} \mathrm{Ne} /{ }^{22} \mathrm{Ne}$ & $\mathbf{s}$ & ${ }^{21} \mathrm{Ne} /{ }^{22} \mathrm{Ne}$ & $\mathbf{s}$ & $\begin{array}{c}{ }^{22} \mathrm{Ne} \\
\left(10^{-8} \mathrm{ccSTP} / \mathrm{g}\right)\end{array}$ & ${ }^{4} \mathrm{He} /{ }^{22} \mathrm{Ne}$ & $\mathbf{s}$ & $R / R a_{c}$ & $\mathbf{s}$ & ${ }^{4} \mathrm{He}^{3} \mathrm{He}_{\mathrm{c}}$ \\
\hline GUA07_BJ & \multirow{3}{*}{ Bains Jaunes } & \multirow{3}{*}{16.03471} & \multirow{3}{*}{-61.67014} & \multirow{3}{*}{981} & 31.4 & 1.02 & 0.10 & 4.65 & 9.91 & 0.18 & 0.0291 & 0.0001 & 1.53 & 3.0 & 0.2 & \multirow{3}{*}{\multicolumn{3}{|c|}{ no correction ${ }^{*}$}} \\
\hline GUA09_BJ & & & & & 33.9 & 1.38 & 0.04 & 4.49 & 9.83 & 0.05 & 0.0290 & 0.0002 & 1.45 & 3.1 & 0.2 & & & \\
\hline GUA10_BJ & & & & & 29.4 & 1.40 & 0.06 & 4.27 & 9.79 & 0.02 & 0.0293 & 0.0003 & 1.49 & 2.9 & 0.1 & & & \\
\hline GUA07_RM & \multirow{3}{*}{$\begin{array}{c}\text { Ravine } \\
\text { Marchand }\end{array}$} & \multirow{3}{*}{16.04222} & \multirow{3}{*}{-61.67248} & \multirow{3}{*}{1015} & 4.9 & 7.66 & 0.52 & 17.2 & 9.96 & 0.06 & 0.0294 & 0002 & 0.47 & 36.6 & 2.5 & 8.2 & 0.6 & 87,400 \\
\hline GUA09_RM & & & & & 48.4 & 7.54 & 0.13 & 19.9 & 9.98 & 0.06 & 0.0297 & 0.0004 & 0.46 & 43.1 & 1.3 & 8.0 & 0.1 & 89,700 \\
\hline GUA10_RM & & & & & 42.9 & 7.45 & 0.27 & 21.6 & 9.78 & 0.02 & 0.0287 & 0.0003 & 0.67 & 32.6 & 0.8 & 8.0 & 0.3 & 89,100 \\
\hline GUA07_GAB & \multirow{3}{*}{ Galion Blanc } & \multirow{3}{*}{16.03745} & \multirow{3}{*}{-61.66434} & \multirow{3}{*}{1100} & 41.4 & 6.76 & 0.47 & 6.28 & 10.02 & 0.06 & 0.0290 & 0.0005 & 0.42 & 15.1 & 1.0 & 8.0 & 0.6 & 89,500 \\
\hline GUA09_GAB & & & & & 41.6 & 5.27 & 0.10 & 4.99 & 9.79 & 0.05 & 0.0293 & 0.0004 & 0.61 & 8.2 & 0.4 & 7.3 & 0.2 & 98,400 \\
\hline GUA10_GAB & & & & & 42.8 & 5.94 & 0.22 & 6.11 & 9.82 & 0.02 & 0.0292 & 0.0003 & 0.61 & 10.1 & 0.3 & 7.7 & 0.3 & 93,000 \\
\hline GUA07_GA & \multirow{3}{*}{ Galion } & \multirow{3}{*}{16.03745} & \multirow{3}{*}{-61.66434} & \multirow{3}{*}{1100} & 45.7 & 5.91 & 0.42 & .70 & 10.04 & 0.06 & 0.0294 & .0002 & 0.42 & 10.6 & 0.7 & 7.5 & 0.6 & 95,000 \\
\hline GUA09_GA & & & & & 45.8 & 5.47 & 0.11 & 4.56 & 9.89 & 0.05 & 0.0291 & 0.0003 & 0.49 & 9.4 & 0.5 & 7.2 & 0.2 & 99,500 \\
\hline GUA10_GA & & & & & 45.9 & 5.35 & 0.20 & 5.49 & 9.79 & 0.03 & 0.0294 & 0.0003 & 0.62 & 8.9 & 0.3 & 7.2 & 0.3 & 99,600 \\
\hline \multirow{2}{*}{$\begin{array}{l}\text { GUA07_CE } \\
\text { GUA09_CE }\end{array}$} & \multirow{2}{*}{$\begin{array}{l}\text { Carbet } \\
\text { Echelle }\end{array}$} & \multirow{2}{*}{16.04487} & \multirow{2}{*}{-61.65706} & \multirow{2}{*}{1146} & 20.9 & 6.61 & 0.45 & 17.6 & 9.71 & 0.06 & 0.0288 & 0.0001 & 1.43 & 12.3 & 0.8 & 8.1 & 0.6 & 87,800 \\
\hline & & & & & 20.3 & 6.55 & 0.11 & 19.1 & 9.81 & 0.05 & 0.0289 & 0.0002 & 1.41 & 13.6 & 0.7 & 7.9 & 0.2 & 91,000 \\
\hline GUA07_PR & \multirow{3}{*}{ Pas du Roy } & \multirow{3}{*}{16.03455} & \multirow{3}{*}{-61.66922} & \multirow{3}{*}{1008} & 3 & 77 & 0.20 & 5 & 9.77 & 0.06 & & 0001 & 1. & 3.7 & 0.3 & \multirow{3}{*}{\multicolumn{3}{|c|}{ no correction* }} \\
\hline GUA09_PR & & & & & 33.9 & 2.88 & 0.06 & 5.06 & 9.80 & 0.05 & 0.0288 & 0.0002 & 1.33 & 3.8 & 0.2 & & & \\
\hline GUA10_PR & & & & & 34.2 & 2.65 & 0.10 & 5.59 & 9.77 & 0.02 & 0.0288 & 0.0002 & 1.50 & 3.7 & 0.1 & & & \\
\hline GUA07_CC & Chute du & 1604380 & -6164470 & 605 & 44.5 & 5.22 & 0.36 & 14.1 & 9.61 & 0.06 & 0.0289 & 0.0002 & 1.43 & 9.8 & 0.7 & 6.8 & 0.5 & 106,000 \\
\hline GUA10_CC & Carbet & 16.04380 & -61.64470 & 605 & 44.7 & 4.88 & 0.18 & 16.0 & 9.80 & 0.02 & 0.0290 & 0.0002 & 1.75 & 9.2 & 0.2 & 6.4 & 0.3 & 111,000 \\
\hline GUA07_BCM & Bains Chauds & 16.05006 & -61.67430 & 1055 & 58.5 & 4.38 & 0.31 & 16.5 & 9.73 & 0.06 & 0.0290 & 0.0001 & 3.23 & 5.1 & 0.3 & 8.0 & 0.8 & 89,400 \\
\hline GUA09 TA & rado & 5 & C1 ccono & 1 & 41.4 & 3.75 & 0.07 & 6.71 & 9.91 & 0.05 & 0.0296 & 0.0003 & 1.30 & 5.2 & 0.1 & 6.5 & 0.2 & 109,000 \\
\hline GUA10_TA & Tarade & 16.03715 & -61.66800 & 1079 & 39.4 & 3.49 & 0.14 & 5.44 & 9.79 & 0.02 & 0.0291 & 0.0003 & 1.34 & 4.1 & 0.1 & 8.0 & 0.6 & 90,000 \\
\hline GUA09_HR & Habitation & & & & 31.2 & 4.51 & 0.08 & 1.42 & 9.79 & 0.05 & 0.0285 & 0.0003 & 1.41 & 10.1 & 0.5 & 5.7 & 0.1 & 125,000 \\
\hline GUA10_HR & Revel & 05029 & 69711 & 609 & 33.4 & 3.49 & 0.13 & 8.78 & & no & data & & 1.61 & 5.5 & 0.1 & 5.8 & 0.3 & 124,000 \\
\hline
\end{tabular}

$\mathrm{R}={ }_{3} \mathrm{He} /{ }_{4} \mathrm{He}$ and $\mathrm{R}=\left({ }_{3} \mathrm{He} /{ }_{4} \mathrm{He}\right)=1.4 \times 10$

Subscript "m" indieates measuredr data, subscript "c" indicates ASW correction based on ratio ${ }_{4} \mathrm{He} /{ }_{22} \mathrm{Ne}$ ). *corrected ratio cannot be obtained because of ${ }_{4} \mathrm{He} /{ }_{22} \mathrm{Ne}$ ratio close to the ASW value.

note that ${ }^{4} \mathrm{He} /{ }^{3} \mathrm{He}$ is equal to $92,600 \pm 2,400(7.8 \pm 0.2 \mathrm{Ra})$ in 2007 and $95,070 \pm 3,800(7.63 \pm 0.3 \mathrm{Ra})$ in 2010 . Correction for air contamination using the measured ${ }^{4} \mathrm{He} /{ }^{20} \mathrm{Ne}$ ratios and considering a pure air origin for neon, yields $\left({ }^{4} \mathrm{He} /{ }^{3} \mathrm{He}\right)_{c}=91,500\left(\mathrm{R} / \mathrm{R}_{\mathrm{a}}=7.9\right)$ and 89,200 $\left(R / R_{a}=8.1\right)$, indicating that fumarole samples contain a MORB signal. Pedroni et al. (1999) measured helium isotopes in fumarole gases and obtained $R_{c} / R_{a}$ ratios of 8.32 and 8.46 with ${ }^{4} \mathrm{He}$ abundances of $4.95 \mathrm{ppm}$ and $6.35 \mathrm{ppm}$ respectively. The neon and argon isotopic data show a mass-dependant fractionation process leading to enrichment light isotopes.

\section{Discussion}

\subsection{Crustal contamination of groundwaters}

As shown previously, two samples (Chute du Carbet and Habitation Revel) tend to display higher ${ }^{4} \mathrm{He} /{ }^{3} \mathrm{He}$ than other samples $(108,000 \pm$ 4,000 and $124,000 \pm 400$ respectively). Magma source contamination by the subducting slab can be ruled out for the arc centre islands (Dominica, Guadeloupe and Montserrat), which display MORB isotopic ratios (van Soest et al., 1998; Pedroni et al., 1999). The most

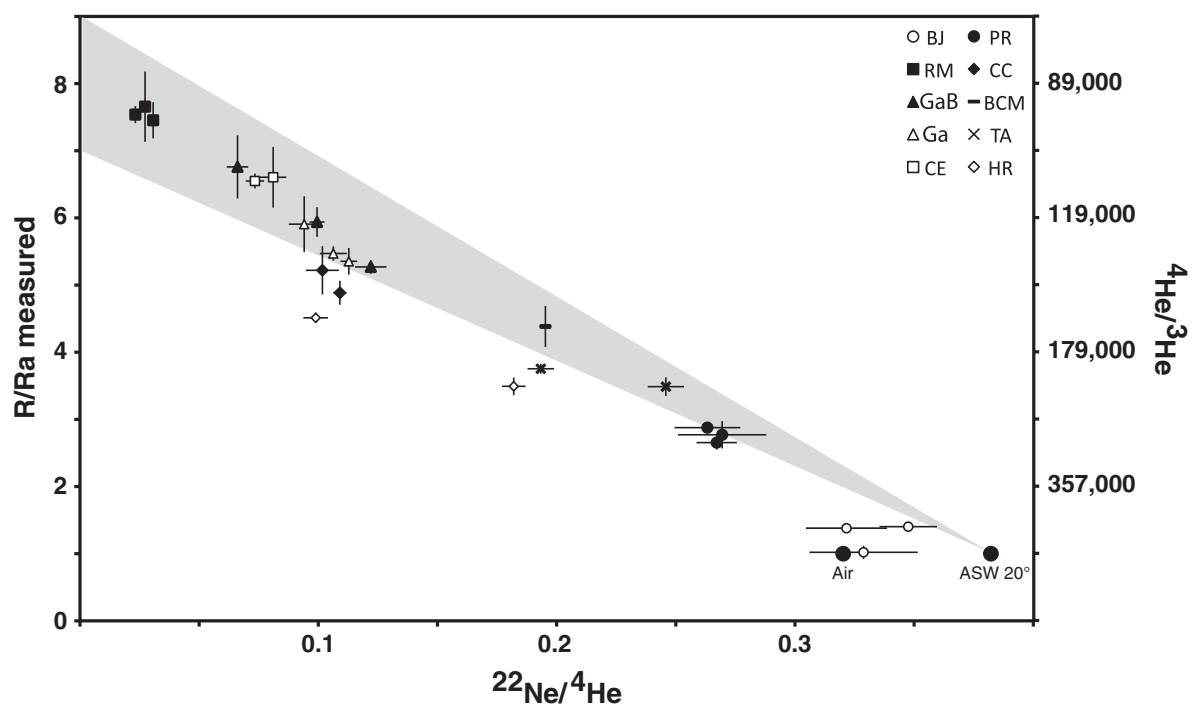

Fig. 2. Plot of measured R/Ra against ${ }^{22} \mathrm{Ne} /{ }^{4} \mathrm{He}$. BJ is for Bains Jaunes, PR Pas du Roy, RM Ravine Marchand, CC Chute du Carbet, GaB Galion Bis, Ga Galion, BCM Bains Chauds du Matouba, TA Tarade, CE Carbet Echelle, HR Habitation Revel. The grey shaded region shows mixing between ASW $20{ }^{\circ} \mathrm{C}$ and MORB source mantle (R/Ra $8 \pm 1$ ). Air end-member seems to strongly influence Bains Jaunes. 
Table 2

Concentrations (in ppm per volume) and isotopic ratios measured in South Crater fumarole in 2007 and 2010. * Gas1995 data from Pedroni et al. (1999). The fractionation factor is expressed as $\mathrm{F}(\mathrm{X})=\left(\mathrm{X} /{ }^{36} \mathrm{Ar}\right)_{\text {sample }} /\left(\mathrm{X} /{ }^{36} \mathrm{Ar}\right)_{\text {air. }}$.

\begin{tabular}{lllll}
\hline & Gas2007 & Gas2010 & Gas1995* & Air \\
\hline${ }^{4} \mathrm{He}(\mathrm{ppm})$ & 5.32 & 6.78 & 5.65 & 5.24 \\
${ }^{20} \mathrm{Ne}(\mathrm{ppm})$ & 0.12 & 1.18 & 0.02 & 16.45 \\
${ }^{36} \mathrm{Ar}(\mathrm{ppm})$ & 0.40 & 2.24 & 0.024 & 31.42 \\
${ }^{84} \mathrm{Kr}(\mathrm{ppm})$ & 0.013 & 0.061 & & 0.65 \\
${ }^{132} \mathrm{Xe}(\mathrm{ppm})$ & 0.001 & 0.007 & & 0.02 \\
$\mathrm{Rm} / \mathrm{Ra}$ & $\mathbf{7 . 8} \pm \mathbf{0 . 2}$ & $\mathbf{7 . 6} \pm \mathbf{0 . 3}$ & $\mathbf{8 . 3}$ & $\mathbf{1}$ \\
${ }^{20} \mathrm{Ne} /{ }^{22} \mathrm{Ne}$ & $9.98 \pm 0.03$ & n.m & 9.92 & 9.8 \\
${ }^{21} \mathrm{Ne} /{ }^{22} \mathrm{Ne}$ & $0.0293 \pm 0.0002$ & n.m & & 0.029 \\
${ }^{38} \mathrm{Ar} /{ }^{36} \mathrm{Ar}$ & $0.1866 \pm 0.0004$ & n.m & & 0.1880 \\
${ }^{40} \mathrm{Ar} /{ }^{36} \mathrm{Ar}$ & $290 \pm 3$ & n.m & 312 & 295.5 \\
${ }^{129} \mathrm{Xe} /{ }^{130} \mathrm{Xe}$ & $6.6 \pm 0.1$ & n.m & & 6.5 \\
${ }^{4} \mathrm{He} /{ }^{22} \mathrm{Ne}$ & 442 & 56.3 & & \\
$\mathrm{~F}\left({ }^{4} \mathrm{He}\right)$ & 79.4 & 18.1 & & \\
$\mathrm{~F}\left({ }^{20} \mathrm{Ne}\right)$ & 0.55 & 1.01 & & \\
$\mathrm{~F}\left({ }^{84} \mathrm{Kr}\right)$ & 1.59 & 1.31 & & \\
$\mathrm{~F}\left({ }^{132} \mathrm{Xe}\right)$ & 3.03 & 4.02 & & \\
\hline
\end{tabular}

straightforward explanation for this discrepancy is contamination by radiogenic helium produced by radioactive decay of $U$ and Th during water-rock interaction in old lava and associated material (Sano et al., 1984; Marty et al., 1989; van Soest et al., 1998). These interactions could occur in the aquifer. In fact, the aquifer of Chute du Carbet is located in the massive andesitic lava unit of Grande-Découverte, which is between 140,000 and 42,000 years old. The aquifer of Habitation Revel is situated in deposits coming from the Grande-Découverte edifice collapse.

\subsection{Superficial fluxes of ${ }^{3} \mathrm{He}$}

At the surface, non-eruptive volcanic emission pathways vary: fumaroles, hot springs or acid crater lakes. Moreover, significant fluxes of gases can be discharged over a wide area through the diffusive leak of $\mathrm{CO}_{2}$ (Allard et al., 1998). The total ${ }^{3} \mathrm{He}$ flux is difficult to estimate and the fluxes discussed below are most probably underestimated. In order to estimate ${ }^{3} \mathrm{He}$ flux through springs, we need to know the water flow in each spring. Systematic measurements of spring flow by the Observatory began in 1995 for Galion, Pas du Roy and Tarade. The monitoring began regularly in 1999 for Carbet Echelle and in 2000 for Ravine Marchand (OVSG, 1999-2011). ${ }^{3} \mathrm{He}$ ranges between $5 \times 10^{-13} \mathrm{cc} / \mathrm{g}$ (Galion) and $1.4 \times 10^{-12} \mathrm{cc} / \mathrm{g}$ (Carbet Echelle). Taking into account the following flows: $150 \mathrm{l} / \mathrm{min}$ for Galion, $125 \mathrm{l} / \mathrm{min}$ for Tarade, 22 l/min for Pas du Roy, 20 l/min for Ravine Marchand and $3.3 \mathrm{l} / \mathrm{min}$ Carbet Echelle, calculated fluxes vary between $7.4 \times$ $10^{-11} \mathrm{cc} / \mathrm{s}$ (Pas du Roy) and $1.3 \times 10^{-9} \mathrm{cc} / \mathrm{s}$ (Galion). Total ${ }^{3} \mathrm{He}$ flux over three years for these five springs is equal to $0.11 \mathrm{cc} /$ year.

The total gas flux of the fumarole at South Crater has been determined to be around $10 \mathrm{~m}^{3} / \mathrm{s}$ by both acoustic measurements, giving access to speed and thus flux (Dupont, 2010) and infrared temperature measurements using dilution phenomena (F. Beauducel, pers. com.). Since 1976, gas analyses have been regularly performed by gas chromatography (until 2001) then by quadrupole mass spectrometry (OVSG, 1999-2011). Gas analyses of the sample from South Crater vent showed that: (1) the most abundant gas released is water (95 to 98\% of the total volume) (Bernard et al., 2006; Bagnato et al., 2009); (2) the other components in the residual gas are $\mathrm{CO}_{2}$ (65-70\% $\mathrm{mol}$ ), $\mathrm{H}_{2} \mathrm{~S}$ (22-32\%), $\mathrm{SO}_{2}(0.2-0.55 \%)$ and $\mathrm{CH}_{4}(0.1-0.4 \%)$ and the three diatomic gases, $\mathrm{H}_{2}, \mathrm{~N}_{2}$ and $\mathrm{O}_{2}$ (respectively, $0.6 \%, 1.5 \%, 0.05 \%$ mol) (OVSG, 1999-2011; Bagnato et al., 2009).

In 2007, we measured a ${ }^{3} \mathrm{He}$ concentration in dry gas of around $5.8 \times 10^{-11} \mathrm{ppm}$. In the total fumarole, this corresponds to $1.2-2.9 \times 10^{-12} \mathrm{ppm}$, depending on the water content (between $95 \%$ and $98 \%$ ), and represents a ${ }^{3} \mathrm{He}$ flux between $1.2 \times 10^{-5}$ and $3 \times 10^{-5} \mathrm{cc} / \mathrm{s}$. For the 2010 gas sample, we obtained a ${ }^{3} \mathrm{He}$ concentration in the dry gas of around $7.2 \times 10^{-11} \mathrm{ppm}$, representing a ${ }^{3} \mathrm{He}$ flux between $1.5-3.6 \times 10^{-5} \mathrm{~cm}^{3} / \mathrm{s}$. This corresponds to a ${ }^{3} \mathrm{He}$ flux of $400 \mathrm{cc} /$ year for the Crater South fumarole. This is obviously much higher than the flux from thermal springs ( $0.11 \mathrm{cc} /$ year). Thus, fumaroles are an efficient pathway to degas helium, as previously observed at Mount Etna (Allard et al., 1997).

\section{3. ${ }^{3}$ He magma chamber degassing time}

During periods of volcanic inactivity, magmatic degassing is mainly controlled by system cooling which induces crystallization and/or by magma mixing affecting the stability of volatile species. When a dense mafic magma is injected into an intermediate or silicic reservoir, the induced cooling and crystallization of the mafic melt causes volatile exsolution. We would like to constrain the time needed to degas ${ }^{3} \mathrm{He}$ from the magma chamber.

We measured a ${ }^{4} \mathrm{He} /{ }^{3} \mathrm{He}$ ratio of around 89,000 in most of the fluid samples, showing a negligible sediment contribution beneath Guadeloupe. This is in strong agreement with other rare gas studies on the Lesser Antilles arc (Mitchell and Terrel, 1983; van Soest et al., 1998; Pedroni et al., 1999) and with inferences from U-series isotopes (Turner et al., 1996; Chabaux et al., 1999; DuFrane et al., 2009). As no helium is added in the magma source beneath Guadeloupe, we can consider the source to be similar to the MORB source. Upper-mantle He concentrations are difficult to determine. The highest value has been measured in popping rock samples that display a ${ }^{4} \mathrm{He}$ concentration around $10^{-5} \mathrm{cc} / \mathrm{g}$ (Javoy and Pineau, 1991; Moreira et al., 1998). As helium is incompatible during melting (Heber et al., 2007), for partial melting of $10 \%$ in the mantle wedge (Turner et al., 1996), ${ }^{3} \mathrm{He}$ concentration is estimated around $10^{-9} \mathrm{cc} / \mathrm{g}$ in the magma considering a ${ }^{4} \mathrm{He} /{ }^{3} \mathrm{He}$ ratio of $89,000\left({ }^{3} \mathrm{He} /{ }^{4} \mathrm{He}=8 \mathrm{Ra}\right)$. We choose to consider the largest magma chamber size that can be estimated from the volume of eruptive products (Semet et al., 1981). The reservoir size is therefore $\sim 0.1-\mathrm{km}^{3}$ at $6 \mathrm{~km}$ depth.

Considering a constant flux for a single fumarole $\left({ }^{3} \mathrm{He}=400 \mathrm{cc} /\right.$ year), a non-degassed and non-crystallized magma with a density of $2.5 \mathrm{~g} / \mathrm{cm}^{3}$ and no phreatic eruptions since the last magmatic eruption, a simple mass balance calculation indicates that 800 years are needed to fully degas the helium in a $0.1-\mathrm{km}^{3}$ magma chamber. This estimation obviously represents the upper limit of degassing time for the chosen ${ }^{3} \mathrm{He}$ concentration $\left(10^{-9} \mathrm{cc} / \mathrm{g}\right)$. We emphasize that the upper mantle He concentration is based on the popping rock value, which has around ten times higher helium contents than most MORB glasses. Therefore, the estimated initial magmatic ${ }^{3} \mathrm{He}$ concentrations may be overestimated by at least a factor of 10 , implying that the degassing times could also be overestimated by a factor of ten.

We would like to test the effect of degassing and crystallization on the He content of the basic magma entering in the chamber. The low solubilities of helium ( 0.0024 molar at $1.8 \mathrm{Kbar})$ and $\mathrm{CO}_{2}(0.0008$ molar at $1.8 \mathrm{Kbar}$ ) relative to $\mathrm{H}_{2} \mathrm{O}(>0.006$ molar at $1.8 \mathrm{Kbar})$ in basaltic melts mean that the noble gases will follow $\mathrm{CO}_{2}$ in the earlyformed vapour phase in an ascending magma (Caroll and Draper, 1994). Thus, if we consider that the magma is degassed during its ascent through the crust due to decompression prior to entering the magma chamber, the required degassing time of the magma chamber will be shorter. For two extreme cases of magmatic degassing before emplacement in the magma chamber, $90 \%$ and $10 \%$, we obtain respectively 80 years and 700 years to fully degas the magma chamber with the observed helium flux in one fumarole.

We can also to take into account the olivine crystallization process, which increases helium concentration in melt due to its incompatibility $\left(D=1.7 \times 10^{-4}\right)$ (Heber et al., 2007). Poussineau (2005) suggests that injected basaltic melt contains less than $35 \%$ of crystals. Therefore using the fractional crystallization law equation, helium concentration increases by $33 \%$ in melt. If the magma chamber is totally filled, the degassing time will be increased by 200 years. 
As mentioned previously, the magma chamber is chemically and thermally zoned (Poussineau, 2005). Periodically this chamber is fed by fresh batches of basaltic magma. When a large batch is emplaced, mechanical mixing occurs between fresh and andesitic magma leading to chamber instabilities triggering the eruption. As no magmatic eruption has occurred since $1530 \mathrm{AD}$, we can assume that the fresh magma inputs have small volumes compared to the magma chamber. For example, if only $10 \%$ of the magma chamber is filled, the maximum degassing time will drop to 100 years. We conclude that, since the last magmatic eruption occurred in $1530 \mathrm{AD}$, new batches of magma in the chamber must have been added fairly recently to provide the observed ${ }^{3} \mathrm{He}$ flux.

\section{A scenario for La Soufrière volcanic activity since 1530 A.D.}

Considering our new data combined with prior studies, we propose a global scenario to explain La Soufrière activity since its last magmatic eruption (Fig. 3). A long-lived (up to thousand years) andesitic chamber is located at $6 \mathrm{~km}$ depth (Semet et al., 1981; Touboul et al., 2007). This $0.1-\mathrm{km}^{3}$ chamber is chemically and thermally zoned and behaves as an open system (Poussineau, 2005). Periodically this chamber is fed by fresh batches of basaltic magma. When a bigger batch is emplaced, mechanical mixing occurs between fresh and andesitic magma and leads to chamber instabilities, triggering the eruption. This scenario explains the $1530 \mathrm{AD}$ eruption (Boudon et al., 2008).

In addition, as illustrated in Fig. 3, historical records show two major phreatic eruptions (1797 and 1976), three minor phreatic eruptions (1690,1837 and 1956) and periods of intense phreatic activity $(1645,1696,1812$, with rest periods of around 100 years between each period of activity) (Komorowski et al., 2005). The disequilibrium triggering phreatic eruptions could be explained in two ways: an abnormal energy input from the magmatic chamber (Feuillard et al., 1983) or a clogging of the hydrothermal system (Zlotnicki et al., 1992). Clogging cycles allow significant temperature increases in aquifers and could trigger eruptions similar to that which occurred in 1956 after 120 years of rest. Abnormal energy input from the magma chamber due to new batches of magma or crystallization process seems to be more random.

In 1976, the phreatic eruption occurred 20 years after the previous one. Although hydrothermal activity diminished for a few years, emplacement of a new batch of magma in the magma chamber is probably needed to input energy into the system to trigger a major phreatic eruption. The injection could have occurred prior to 1968. Two indicators seem to confirm this suggestion: seismic activity and temperature changes inside boreholes drilled at Col de l'Echelle (altitude $1253 \mathrm{~m}$, depth $77 \mathrm{~m}$ - Fig. 1C) (Feuillard, 1976). Temperature measurements at $76 \mathrm{~m}$ depth are presented in Fig. 4. Evolution of
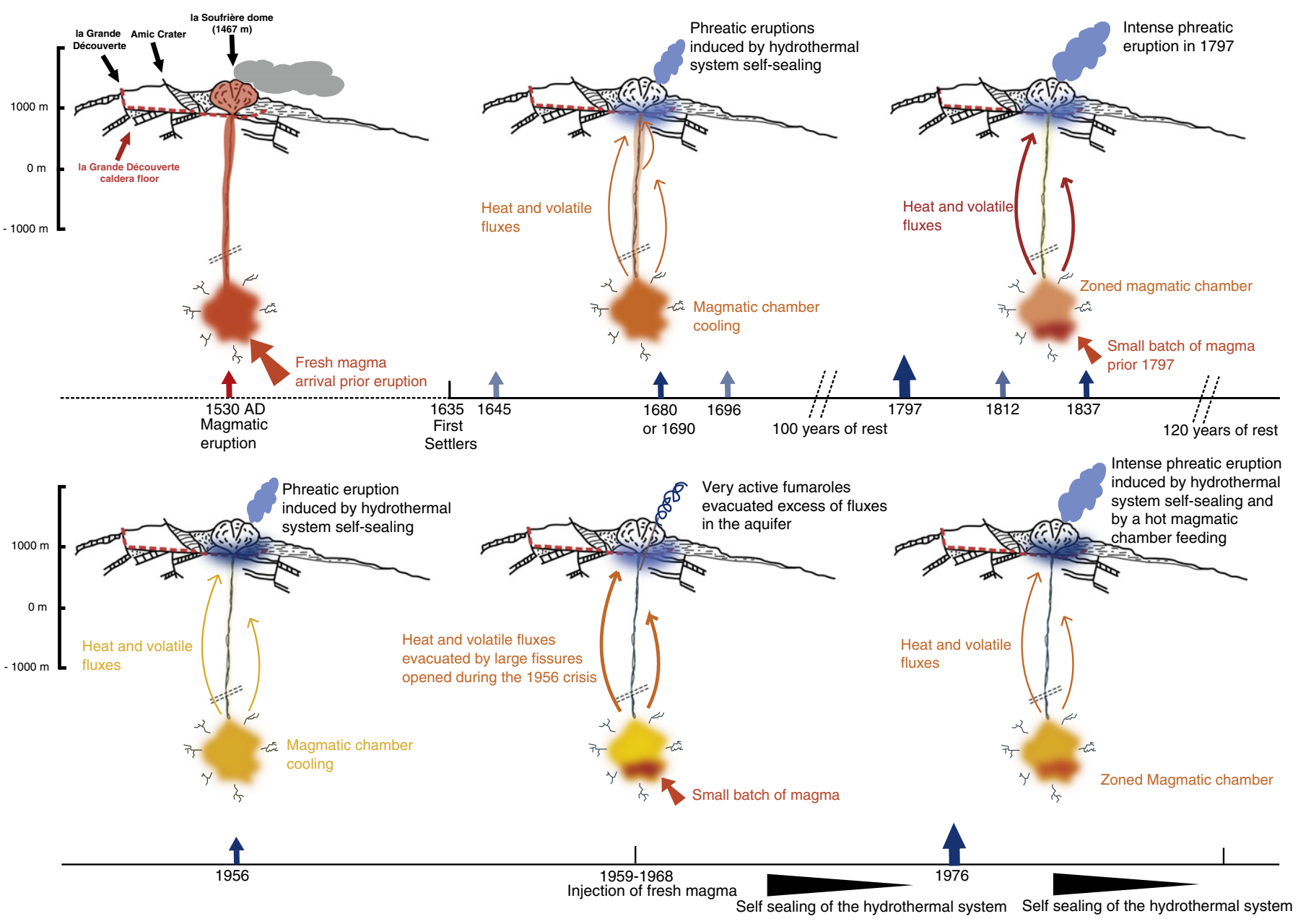

Fig. 3. Sketch representing a scenario for the activity of La Soufrière Volcano since its last magmatic eruption (1530 AD). Each vertical arrow represents phreatic activity: light arrows are intense phreatic activity and dark arrows are well-identified phreatic eruptions. Since $1635 \mathrm{AD}$, when the first settlers arrived, historical eruptive activity has exclusively consisted of phreatic eruptions (Komorowski et al., 2005). Very intense phreatic activity has been reported for 1645 (DuTertre, 1654) and 1696 (Labat, 1722). An additional phreatic eruption seems to have occurred in 1680 or 1690 (Ballet, 1896). After 100 years of rest, phreatic activity started again in 1797 with a huge crisis (Amic et al., 1798) followed by smaller crises in 1812 and 1837 (Lherminier, 1837). After 120 years of rest, a new cycle started again in 1956 (Jolivet, 1956) with the last phreatic eruption occuring in 1976-1977. Our interpretation of magma chamber replenishments is based on geophysical data for the 1976/77 crisis and literature for the 1797 crisis (Amic et al., 1798). 
the temperature curve with time is remarkable. Between 1968 and 1976 the temperature is constant at around $101.25^{\circ} \mathrm{C}$. Just after the crisis, the temperature starts to slowly decrease to its current temperature of $19{ }^{\circ} \mathrm{C}$. Heat input is clearly present at least 8 years before the crisis. Furthermore, the number of earthquakes per year (Fig. 4) after the 1956 phreatic eruption slightly decreases until 1959. From 1960 to 1961 , no data are available. In 1962, the number of earthquakes increases (313 per year). During the 1963-75-time span, the number of earthquakes is between 45 and 295 with an average of 156 quakes/ year. We speculate that a new batch of magma could have arrived in the magma chamber between 1959 and 1962. However, no eruption occurred because cracks did not have sufficient time to seal themselves after the previous eruption in 1956.

Furthermore, considering that the 1797 eruption follows exactly the same eruptive sequence and intensity as the 1976 eruption (Barat, 1986), we suggest that a new batch of magma was emplaced prior to this eruption. This could explain the increase of felt seismicity in terms of both frequency and magnitude a few years before the eruption (Amic et al., 1798).

To conclude, we suggest that minor eruptions and periods of intense activity could be explained by self-sealing of the hydrothermal system while major phreatic eruptions need the emplacement of a small fresh batch of magma in the chamber, in addition to the clogging of the hydrothermal system.

\section{Conclusions}

Using noble gas systematics, we have shown that summit fumaroles represent a mixture between meteoric water and a magmatic flux component. All thermal springs are the result of mixing between meteoric water percolating through different deposits and magmatic fluids. Shallow contamination adding ${ }^{4} \mathrm{He}$ to water is clearly established in two springs (Chute du Carbet and Habitation Revel). A clear MORB signal $\left({ }^{4} \mathrm{He} /{ }^{3} \mathrm{He}\right.$ around 89,000$)$ is recorded in all fluid samples demonstrating that contributions from the subducting slab to the mantle wedge are minor. Thanks to systematic monitoring performed by the Volcanological Observatory, ${ }^{3} \mathrm{He}$ fluxes in both springs and fumaroles could be estimated. We have calculated that ${ }^{3} \mathrm{He}$ flux is much higher in fumaroles than in springs, showing that fumaroles are the most efficient pathways to degas the magmatic system. By a simple mass balance calculation, we also conclude that the magma chamber must be regularly fed by new batches of magma to maintain the observed ${ }^{3} \mathrm{He}$ flux.

Using a combination of historical eruption records, seismic data, borehole temperature measurements and our new measurements of helium, we propose a model to describe La Soufrière's volcanic activity since its last magmatic eruption in $1530 \mathrm{AD}$. We conclude that the activity is controlled by both a random energy input from the magmatic chamber due to the emplacement of new batches of magma, and clogging/opening cycles of the hydrothermal system. Concerning the debated origin of the last crisis (still-born magmatic origin versus pure hydrothermal system control), we propose that both of these factors played a role. We suggest that a new batch of magma was emplaced prior to 1968 (possibly between 1959 and 1962). However, the hydrothermal system was not totally clogged, preventing the system from entering into an overpressurized state. Heat transfer through the edifice was still fairly efficient because of fracture activation during the 1956 crisis. Only when the cracks became completely clogged and sealed did the pressure and temperature in the aquifers rapidly increase to trigger a crisis.

Between 1977 and 1992, we observed again a decay of the hydrothermal activity in the summit. In 1992, the seismic activity started to increase and fumarolic activity clearly increased in December 1997 with significant degassing of $\mathrm{HCl}$ in the summit fumarole (Bernard et al., 2006). However, we are not able to determine with our temporally limited data set if a new magmatic injection occurred during this period.

\section{Acknowledgements}

We thank H. Sumino and M. Kurz for their constructive reviews. We benefited from the invaluable help from the whole staff of the Observatoire Volcanologique et Sismologique de la Guadeloupe. C. Aubaud and F. Beauducel made helpful reviews of draft of this

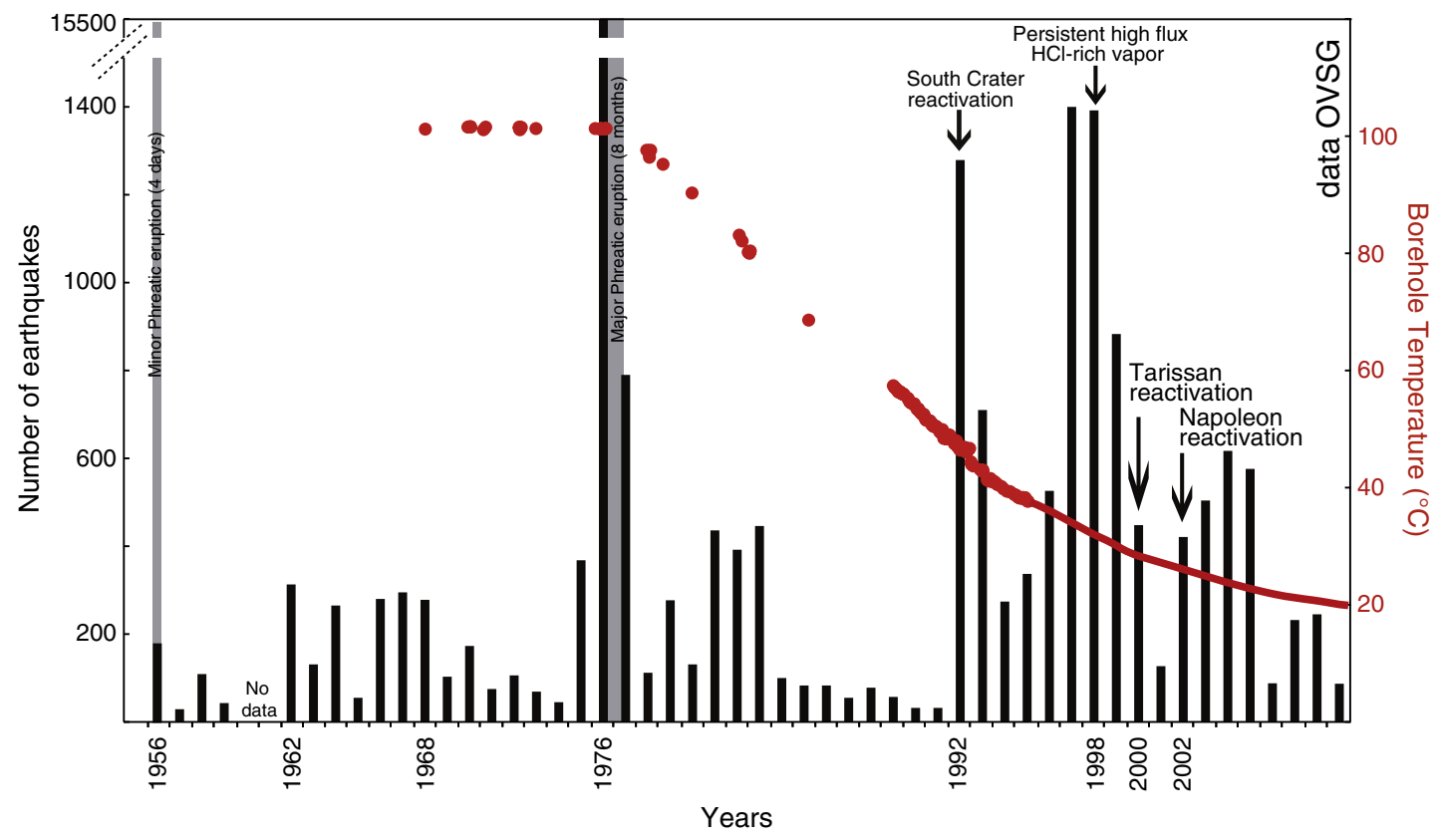

Fig. 4. Temperature variations with time between 1968 and 2010 in Col de l'Echelle borehole (at -76 m) and histogram of the number of recorded earthquakes per year from 1956 to 2010 The two phreatic eruptions (1956 and 1976-77) are indicated with grey bars. After May 1977, fumarolic activity decreased until mid-1980's. In 1992, fumarolic activity increased and three plumes appeared through time: South Crater since 1998, Tarissan vent in 2000 and Napoléon vent in 2002 (Bernard et al., 2006; Nicollin et al., 2006, 2007). 
paper. Thanks to A. Shaw and C. Dessert for fruitful discussions. This is IPGP contribution 3260.

\section{References}

Allard, P., Delibrias, G., Dimon, B., Labeyrie, J., 1983. Implications of carbon and helium isotopes in volcanic gases from la Soufrière of Guadeloupe, Lesser Antilles (abstract). Proc. IAVCEI Symp. on Volcanic Gases, Hambourg, 43.

Allard, P., Jean-Baptiste, P., D'Alessandro, W., Parello, F., Parisi, B., Flehoc, C., 1997. Mantle-derived helium and carbon in groundwaters and gases of Mount Etna, Italy. Earth and Planetary Science Letters 148 (3-4), 501-516.

Allard, P., Hammouya, G., Parello, F., 1998. Diffuse magmatic soil degassing at Soufrière of Guadeloupe, Antilles. Compte-rendu Académie des Sciences de Paris 327, 315-318.

Allègre, C.J., Moreira, M., Staudacher, T., 1995. ${ }^{4} \mathrm{He} /{ }^{3} \mathrm{He}$ dispersion and mantle convection. Geophysical Research Letters 22 (17), 2325-2328.

Amic, Hapel, Laschesnaie, Fontelliau, Code, 1798. Rapport fait en citoyens Victor Hugues et Lebas: Pour examiner la situation du volcan de la Guadeloupe et les effets de l'éruption...(French Document).

Bagnato, E., Allard, P., Parello, F., Aiuppa, A., Calabrese, S., Hammouya, G., 2009. Mercury gas emissions from La Soufrière Volcano, Guadeloupe Island (Lesser Antilles). Chemical Geology 266 (3-4), 267-273.

Ballet, J., 1896. La Guadeloupe, Basse-Terre. Imprimerie du Gouvernement (French Document).

Barat, A., 1986. Etude du rôle des eaux souterraines dans le mécanisme des éruptions phréatiques. Application à la Montagne Pelée de Martinique et à la Soufrière de Guadeloupe, BRGM document (French Document).

Benauges, S., 1981. Etude géochimique et isotopique et circulation des eaux de sources chaudes, sources froides et rivières aux abords du volcan de la SoufrièreGuadeloupe, Université Pierre et Marie Curie, Thesis.

Bernard, M.-L., Molinié, J., Petit, R.-H., Beauducel, F., Hammouya, G., Marion, G., 2006. Remote and in situ plume measurements of acid gas release from La Soufrière volcano, Guadeloupe. Journal of Volcanology and Geothermal Research 150 (4), 395-409.

Bigot, S., Boudon, G., Semet, M., Hammouya, G., 1994. Traçage chimique de la circulation des eaux souterraines sur le volcan de la Grande Découverte (La Soufrière), Guadeloupe. Comptes Rendus de l'Académie des Sciences - Series IIA - Earth and Planetary Science 318, 1215-1221.

Boichu, M., Villemant, B., Boudon, G., 2008. A model for episodic degassing of an andesitic magma intrusion. Journal of Geophysical Research 113 (B07202), 18.

Boudon, G., Semet, M.P., Vincent, P.M., 1987. Magma and hydrothermally driven sector collapses: The 3100 and 11,500 y. B.P. eruptions of la Grande Decouverte (la Soufrière) volcano, Guadeloupe, French West Indies. Journal of Volcanology and Geothermal Research 33 (4), 317-323.

Boudon, G., Komorowski, J.-C., Villemant, B., Semet, M.P., 2008. A new scenario for the last magmatic eruption of La Soufrière of Guadeloupe (Lesser Antilles) in 1530 A.D. Evidence from stratigraphy radiocarbon dating and magmatic evolution of erupted products. Journal of Volcanology and Geothermal Research 178 (3), 474-490.

Brombach, T., Marini, L., Hunziker, J.-C., 2000. Geochemistry of the thermal springs and fumaroles of Basse-Terre Island, Guadeloupe, Lesser Antilles. Bulletin of Volcanology 61 (7), 477-490.

Caroll, M.R., Draper, D.S., 1994. Noble gases as trace elements in magmatic processes. Chemical Geology 117, 37-56.

Chabaux, F., Hémond, C., Allègre, C.J., $1999 .{ }^{238} \mathrm{U}-{ }^{230} \mathrm{Th}-{ }^{226} \mathrm{Ra}$ disequilibria in the Lesser Antilles arc: implications for mantle metasomatism. Chemical Geology 153 (1-4), 171-185.

Drescher, J., Kirsten, T., Schoefer, K., 1998. The rare gas inventory of the continental crust, recovered by the KTB Continental Deep Drilling Project. Earth and Planetary Science Letters 154 (1-4), 247-263.

DuFrane, S.A., Turner, S., Dosseto, A., van Soest, M., 2009. Reappraisal of fluid and sediment contributions to Lesser Antilles magmas. Chemical Geology 265 (3-4), 272-278.

Dupont, A., 2010. Étude du son produit par la Soufrière de Guadeloupe et le Piton de la Fournaise : implications pour la dynamique éruptive et la surveillance volcanique, IPGP thesis, Paris.

DuTertre, J., 1654. Histoire générale des isles de S. Christophe, de la Guadeloupe, de la Martinique, et autres dans l'Amérique. Chez Jacques Langlois et Emmanuel Langlois, Paris (French Document). .

Feuillard, M., 1976. Etudes thermiques à la Soufrière de Guadeloupe. Bulletin BRGM 375-388 (2ème édition, section IV).

Feuillard, M., Allègre, C.J., Brandeis, G., Gaulon, R., Le Mouel, J.L., Mercier, J.C., Pozzi, J.P., Semet, M.P., 1983. The 1975-1977 crisis of la Soufrière de Guadeloupe (F.W.I): A still-born magmatic eruption. Journal of Volcanology and Geothermal Research 16 (3-4), 317-334.

Heber, V.S., Brooker, R.A., Kelley, S.P., Wood, B.J., 2007. Crystal-melt partitioning of noble gases (helium, neon, argon, krypton, and xenon) for olivine and clinopyroxene. Geochimica et Cosmochimica Acta 71 (4), 1041-1061.

Hilton, D.R., Fischer, T.P., Marty, B., 2002. Noble Gases and Volatile Recycling at Subduction Zones. In: Porcelli, D., Ballentine, C.J., Wieler, R. (Eds.), Noble gases in Geochemistry and Cosmechemistry: Reviews in Mineralogy and Geochemistry, pp. $319-370$.

Hirn, A., Michel, B., 1979. Evidence of migration of main shocks during major seismovolcanic crises of la Soufrière (Guadeloupe, lesser antilles) in 1976. Journal of Volcanology and Geothermal Research 6 (3-4), 295-304
Javoy, M., Pineau, F., 1991. The volatiles record of a "popping" rock from the MidAtlantic Ridge at $14^{\circ} \mathrm{N}$ : chemical and isotopic composition of gas trapped in the vesicles. Earth and Planetary Science Letters 107 (3-4), 598-611.

Jolivet, J., 1956. La crise volcanique de 1956 à la Soufrière de Guadeloupe. Annales Géophysicae 14 (3), 305-323.

Komorowski, J.-C., Boudon, G., Semet, M., Beauducel, F., Antenor-Habazac, C., Bazin, S., Hammouya, G., 2005. Guadeloupe. In: Lindsay, J.M., Robertson, R.E.A., Shepherd, J.B., Ali, S. (Eds.), Volcanic Atlas of the Lesser Antilles. Seismic Research Unit. The University of teh West Indies, Trinidad, pp. 65-102.

Labat, 1722. Nouveau Voyage aux îles de l'Amérique, contenant l'histoire naturelle de ces pays. G Cavelier (French Document).

LeGuern, F.J., Cheynet, B., Fayvre-Pierret, R.X., 1993. Charaterization and modelling of the complete volcanic gas phase. Geochemical Journal 27, 323-326.

Lherminier, F., 1837. Note sur l'éruption du volcan de la Guadeloupe. Compte-rendu de l'Académie des Sciences, Paris iV, 294.

Marty, B., Jambon, A., Sano, Y., 1989. Helium isotopes and $\mathrm{CO}_{2}$ in volcanic gases of Japan. Chemical Geology 76 (1-2), 25-40.

Mitchell, J., Terrel, D., 1983. Inert gas abundances in basalts of the Lesser Antilles island arcs: possible implications for their volcanic evolution. Physics of the Earth and Planetary Interiors 31, 161-170.

Moreira, M., Allègre, C.J., 2002. Rare gas systematics on Mid Atlantic Ridges (37-40 ${ }^{\circ} \mathrm{N}$ ). Earth and Planetary Science Letters 198, 401-416.

Moreira, M., Kunz, J., Allègre, C.J., 1998. Rare gas systematics on popping rock: estimates of isotopic and elemental compositions in the upper mantle. Science 279, 1178-1181.

Moreira, M., Blusztajn, J., Curtice, J., Hart, S., Dick, H., Kurz, M.D., 2003. He and Ne isotopes in oceanic crust: implications for noble gas recycling in the mantle. Earth and Planetary Science Letters 216 (4), 635-643.

Nicollin, F., Gibert, D., Beauducel, F., Boudon, G., Komorowski, J.-C., 2006. Electrical tomography of La Soufrière of Guadeloupe Volcano: Field experiments, 1D inversion and qualitative interpretation. Earth and Planetary Science Letters 244 (3-4), 709-724.

Nicollin, F., Gibert, D., Beauducel, F., Boudon, G., Komorowski, J.-C., 2007. Reply to comment on "Electrical Tomography of La Soufriere of Guadeloupe Volcano: Field experiments, 1D inversion and qualitative interpretation" by N. Linde and A. Revil. Earth and Planetary Science Letters 258 (3-4), 623-626.

OVSG, O.V.e.s.d.l.G., 1999-2011. Bilan mensuel de l'Activité volcanique et de la sismisité régionale de l'Observatoire Volcanologique de la Soufrière. http://volcano.ipgp.fr/ guadeloupe/Infos.htm1999-2011.

Pascaline, H., Benauges, S., Jérémie, J.-J., Blavoux, B., 1982. Hydrochimie et circulation des eaux de sources chaudes du massif de la Soufrière, Guadeloupe. Bulletin Musuem National History Natural 4 (3-4), 137-155.

Pedroni, A., Hammerschmidt, K., Friedrichsen, H., 1999. He, Ne, Ar, and C isotope systematics of geothermal emanations in the Lesser Antilles Islands Arc. Geochimica et Cosmochimica Acta 63 (3-4), 515-532.

Poussineau, S., 2005. Dynamique des magmas andésitiques : approche expérimentale et pétrostructurale; application à la Soufrière de Guadeloupe et à la Montagne Pelée, Université d'Orléans, Orléans, thesis.

Pozzi, J.P., Le Mouël, J.L., Rossignol, J.C., Zlotnicki, J., 1979. Magnetic observations made on la soufriere volcano (guadeloupe) during the 1976-1977 crisis. Journal of Volcanology and Geothermal Research 5 (3-4), 217-237.

Sano, Y., Nakamura, Y., Wakita, H., Urabe, A., Tominaga, T., 1984. ${ }^{3} \mathrm{He}$ emission related to volcanic activity. Science 224 (4645), 150-151.

Semet, M., Vatin Pérignon, N., Vincent, P., Joron, J.L., 1981. L'éruption du XVIème siècle de la Soufrière de Guadeloupe. Mélange de magmas et dynamismes éruptifs: Bulletin PIRPSEV-CNRS, Paris, 60, pp. 1-63.

Staudacher, T., Allègre, C.J., 1988. Recycling of oceanic crust and sediments: the noble gas subduction barrier. Earth and Planetary Science Letters 89 (2), 173-183.

Sumino, H., Notsu, K., Nakai, S., Sato, M., Nagao, K., Hosoe, M., Wakita, H., 2004. Noble gas and carbon isotopes of fumarolic gas grom Iwojima volcano, Izu-Ogasawara-arc, Japan: implications for the origin of unusual arc magmatism. Chemical Geology 209, 153-173.

Touboul, M., Bourdon, B., Villemant, B., Boudon, G., Joron, J.-L., 2007. 238U-230Th226Ra disequilibria in andesitic lavas of the last magmatic eruption of Guadeloupe Soufriere, french Antilles: Processes and timescales of magma differentiation. Chemical Geology 246 (3-4), 181-206.

Turner, S., Hawkesworth, C., van Calsteren, P., Heath, E., Macdonald, R., Black, S., 1996. U-series isotopes and destructive plate margin magma genesis in the Lesser Antilles. Earth and Planetary Science Letters 142 (1-2), 191-207.

van Soest, M.C., Hilton, D.R., Kreulen, R., 1998. Tracing crustal and slab contributions to arc magmatism in the lesser antilles island arc using helium and carbon relationships in geothermal fluids. Geochimica et Cosmochimica Acta 62 (19-20), 3323-3335.

Villemant, B., Hammouya, G., Michel, A., Semet, M.P., Komorowski, J.-C., Boudon, G., Cheminée, J.-L., 2005. The memory of volcanic waters: Shallow magma degassing revealed by halogen monitoring in thermal springs of La Soufrière volcano (Guadeloupe, Lesser Antilles). Earth and Planetary Science Letters 237 (3-4), 710-728.

Zlotnicki, J., Boudon, G., Le Mouël, J.-L., 1992. The volcanic activity of La Soufrière of Guadeloupe (Lesser Antilles): structural and tectonic implications. Journal of Volcanology and Geothermal Research 49 (1-2), 91-104.

Zlotnicki, J., Vargemezis, G., Mille, A., Bruère, F., Hammouya, G., 2006. State of the hydrothermal activity of Soufrière of Guadeloupe volcano inferred by VLF surveys. Journal of Applied Geophysics 58 (4), 265-279. 